\title{
ИССЛЕДОВАНИЯ ПО СЕЙСМОДИНАМИКЕ ПОДЗЕМНЫХ СООРУЖЕНИЙ В СССР И РОССИИ: ИСТОРИЯ, СОВРЕМЕННОЕ СОСТОЯНИЕ И АКТУАЛЬНЫЕ НАПРАВЛЕНИЯ
}

Исраилов М.ШІ. КНИИ им. Х.И. Ибрагимова РАН, г. Грозный

Дан краткий исторический обзор исследований, выполненных в бывшем СССР и России в области сейсмостойкости протяженных подземных сооружений и трубопроводов. Обращено внимание на допущенные в некоторых из них неточности и ошибки, которые могут приводить к неправильным оценкам относительно прочности и устойчивости подобных сооружений при воздействии сейсмических волн. Отмечена роль результатов более строгого подхода, связанного (в отличие от инженерных методов) с исследованием задач сейсмодинамики в связанной постановке, учитывающей совместные колебания сооружения и грунта. Указаны некоторые новые возможные направления исследований в такой постановке.

Ключевые слова: подземные сооружения, сейсмодинамика, недостатки инженерных подходов, новые постановки и решения, актуальные направления исследований.

1. Краткий обзор исследований по сейсмодинамике подземных сооружений, выполненных в СССР и России. Речь, прежде всего, будет идти об исследованиях, связанных с изучением воздействия сейсмических волн на протяженные подземные сооружения (типа трубопроводов и тоннелей) и обеспечением их сейсмостойкости. Такого рода исследования (обычно наряду с исследованием сейсмостойкости наземных сооружений - зданий, мостов, гидроплотин и т. п.) проводились в бывшем Советском Союзе начиная с 30-х40-х годов прошлого столетия как в научных центрах и институтах Академий наук союзных республик (например, Армении, Грузии, Узбекистана, Таджикистана), на территориях, которых проблема сейсмической защиты объектов подземного и наземного строительства являлась актуальной, так и во Всесоюзных научно-исследовательских и проектных институтах ведомственной принадлежности. В качестве примеров можно назвать исследования, проведенные в ВНИИГаз [1] и ВНИИСтройнефть Министерства нефтяной промышленности СССР (ныне ОАО «Институт Нефтегазпроект») [2, 3]. Первые принципы и подходы, лежащие в основе последующих теоретических и экспериментальных исследований в области сейсмодинамики подземных сооружений, были разработаны и/или предложены в упомянутых выше научных учреждениях (мы не приводим здесь имена ученых и исследователей, внесших фундаментальный вклад в эту область и являющихся основателями школ, и направлений, - специалистам они хорошо известны). 
С конца 60-х годов преимущественно в Институте механики и сейсмостойкости АН Узбекской ССР (возникшего в 1966 г. в результате слияния «Института математики и механики» и «Института сооружений» АН УзССР) стали проводиться исследования по сейсмодинамике подземных сооружений под влиянием и с непосредственным участием членакорреспондента АН СССР А.А. Ильюшина $[4,5]$. Примерно в то же время в ЦНИИСК им. В.А. Кучеренко группа проф. Я.М. Айзенберга разрабатывала нормы и правила сейсмостойкого строительства зданий и наземных сооружений (ныне это «Центр исследований сейсмостойкости сооружений» этого института). Такая специализация представляется естественной как в силу специфических особенностей исследуемых проблем, так и, прежде всего, существенного различия в методах экспериментального изучения сейсмического воздействия в случаях подземных и наземных сооружений и используемых для этих целей оборудования и установок. Подобная специализация существует и в США, и в Японии - странах, в которых проводились и проводятся масштабные исследования в области сейсмостойкости сооружений. Так в США в Тихоокеанском центре по сейсмоинженерии при Калифорнийском университете в Беркли (PEER - Pacific Earthquake Engineering Research) исследуется (преимущественно) сейсмостойкость наземных сооружений, а в Междисциплинарном центре сейсмостойкости сооружений при университете Буффало (MCEER) сейсмостойкость подземных конструкций.

После распада Советского Союза сложилось так, что научные разработки в области сейсмодинамики подземных сооружений в России велись и ведутся преимущественно (если не сказать исключительно) в ведомственных научноисследовательских и проектных институтах и учреждениях. В качестве примеров назовем упомянутые выше ВНИИГаз (именуемый ныне Всероссийским институтом природных газов и газовых технологий) и ОАО «Институт Нефтегазпроект», а также НТЦ ЯРБ (Научно-технический центр по ядерной и радиационной безопасности), принадлежащий Ростехнадзору, АО АЭП (Атомэнергопроект), входящий в объединение «Росатом», ООО «НИИ ТНН - Транспортировки нефти и нефтепродуктов», являющееся научноисследовательским подразделением ОАО «Транснефть».

Существующая практика показывает, что в своих исследованиях и расчетах по выработке норм и правил сейсмостойкого строительства подземных объектов (протяженных конструкций и трубопроводов) эти научные и проектные учреждения ограничиваются простейшей теорией [6-8], в которой принимается, что конструкция «жестко» скреплена с грунтом и движется при землетрясении так же, как и грунт. Такое упрощение позволяет сразу вычислить деформации и напряжения в конструкции (скажем, трубопроводе) раз движение грунта задано (определено из сейсмограмм). Сказанное положено в основу, например, новых "Норм проектирования сейсмостойких атомных станций» [9], разработанных совместно «НТЦ по ядерной и радиационной безопасности» и $\mathrm{AO}$ «Атомэнергопроект» (и вступившие в силу с 1 января 2001 
года взамен устаревших). Либо используются результаты, полученные в Институте механики и сейсмостойкости сооружений АН УзССР [10-17], как, например, в «НИИ транспортировки нефти и нефтепродуктов» для проектирования сейсмостойких нефтепроводов Сибири. Однако, научная обоснованность используемых результатов вызывает сомнение (некоторые разъяснения по этому поводу приведены ниже).

2. Необходимость ревизии и пересмотра некоторых положений, результатов и методик в области сейсмодинамики протяженных подземных сооружений. Новые актуальные направления исследований.

2.1. Это факт, что во многих случаях для металлических трубопроводов со сварными стыками расчет по указанной выше простейшей теории жесткого сцепления с грунтом обеспечивает сейсмопрочность трубопровода «с запасом», поскольку эта теория дает верхнюю границу для абсолютных величин напряжений в трубопроводе. По этой причине такие расчеты вполне устраивают инженера и проектировщика.

Однако в случаях сегментных трубопроводов, соединенных сложными стыками с демпфирующими прокладками (резинометаллическими, свинцовыми и т. п.), железобетонных трубопроводов и железобетонных обшивок тоннелей, а также трубопроводов, выполненных из пластиковых и композиционных материалов, может возникать сверхзвуковой режим, когда скорость сейсмической волны в грунте больше скорости продольной волны в трубе. И, как нами показано [18-21], в этих случаях могут иметь место усталостные разрушения трубопроводов (из-за вибраций, наложенных на длинную сейсмическую волну) или разрушения за счет появления резонанса. Принципиально важно отметить, что в рамках названной выше и используемой при разработках норм сейсмостойкости теории жесткого сцепления с грунтом и ее модификаций [22] указанные явления не обнаруживаются.

Здесь, кроме теоретических исследований сейсмического поведения трубопроводов сложной конструкции (сегментных со сложными узлами) и трубопроводов из новых материалов, необходимо решить и практическую проблему нахождения простых конструктивных способов выхода из сверхзвукового режима, а значит и обеспечения сейсмобезопасности подобных сооружений.

2.2. Как было указано, широкий спектр теоретических и экспериментальных исследований в области сейсмического поведения и сейсмостойкости протяженных подземных сооружений (преимущественно трубопроводов) проводился в Узбекистане, в Институте механики и сейсмостойкости сооружений. При детальном рассмотрении этих исследований обнаружилось, что они базируются на сомнительном и проведенном без должного критического анализа переносе основных положений и фактов сейсмодинамики наземных сооружений (оснований и фундаментов) на случай подземных сооружений. В результате оказались неверными дифференциальные уравнения относительного движения трубопровода или сооружения и вызывают сомнение экспериментальные данные о такой существенной 
величине как коэффициент взаимодействия сооружения и грунта, поскольку установки, на которых проводились опыты не воспроизводят адекватно условия сейсмической задачи (эти условия не были поняты и потому игнорировались).

Как следствие решения задач, полученные на основе ошибочных уравнений, не корректны и не могут быть использованы для оценки сейсмостойкости. Задача состоит в исправлении этих решений, а также в проведении опытов заново (на новых установках или в полевых условиях) для перепроверки наиболее значимых экспериментальных данных.

Результатом изложенного, а также путаницей, присущей указанным работам, по-видимому, объясняется полное отсутствие ссылок на них со стороны иностранных исследователей (в столь важной для практических приложений области!), хотя Т.Р. Рашидов представлял результаты своей школы на нескольких международных конференциях по сейсмостойкому строительству и было издано несколько монографий.

2.3. Очевидно, что наиболее полные и достоверные результаты могут быть получены при связанной постановке задачи, учитывающей совместные движения подземного сооружения и грунта.

Такая постановка задач сеймодинамики подземных сооружений нами дана и получены следующие основополагающие результаты [18-21, 23-31]: развит метод «квазиодномерной» деформации грунта, расщепляющий уравнения и существенно упрощающий решение внешней задачи для грунта; на основе дискретной модели трубопровода предложена «аналогия линейной цепочки атомов», позволяющая простым образом получать уравнения совместных сейсмических колебаний подземного сооружения в неупругих (в частности, вязкоупругих) грунтах; используя аппарат механики композитов, выведены усредненные уравнения и исследованы сейсмические колебания периодически неоднородных (двух- и многокомпонентных) сегментных трубопроводов со сложными демпфирующими стыками. Эти результаты позволили выявить новые эффекты и явления, например, возможность появления усталостных разрушений подземного сооружения. Они привели к установлению границ применимости инженерных подходов и к обоснованию предложенных ранее и существенно используемых в исследованиях концепций, и гипотез (например, гипотезы о пропорциональности силы взаимодействия между трубопроводом и грунтом относительному перемещению трубы). В некоторых случаях результаты связанной сейсмодинамики исправляют ошибки и некорректности в существующих инженерных решениях и указывают, в том числе, на неточности, допускаемые в постановке модельных опытов на определение силы (или коэффициента) взаимодействия между трубопроводом и грунтом при землетрясении.

Достигнутые «промежуточные» успехи вовсе не закрывают проблему. Наоборот, здесь некоторые направления лишь только намечены или вовсе даже не затронуты (скажем, нелинейные задачи или связанные задачи о совместных изгибных колебаниях трубопровода и грунта) и необходимы дальнейшие 
исследования для развития этого важного с практической точки зрения раздела сеймодинамики.

\section{Исследование выполнено при финансовой поддержке РФФИ в рамках научного проекта № 20-08-00024.}

\section{Список литературы}

1. Емельянов Л. M. О продольных напряжениях в подземных газопроводных трубах // Труды ВНИИГаз "Вопросы добычи, транспорта и переработки природных газов". М.- Л.: Гостехтопиздат, 1951. С. 177-212.

2. Аронов Р. И., Камеритейн А.Г. Защемление трубопроводов в грунте и особенности их работы в районах горных выработок // Труды ВНИИ Стройнефть. Вып. V. М. - Л.: Гостехтопиздат, 1953. С. 35-53.

3. Аронов Р. И. Действительные условия работы конструкций стальных трубопроводов // Труды ВНИИСтройнефть. Вып. V. М. - Л.: Гостехтопиздат, 1953. С. 54-72.

4. Ильюшин A.A., Рашидов T.P. Упрощение уравнения сейсмодинамики сложных систем подземных сооружений // Изв. АН УзССР. Сер. техн. наук, 1970, № 2. С. 20-30.

5. Ильюшин А.A., Рашидов T.P. О действии сейсмической волны на подземный трубопровод//Изв. АН УзССР. Сер. техн. наук, 1971, №1. С.37-42.

6. Мукурдумов P.M. Вопросы сейсмостойкости подземных трубопроводов. Ташкент: Изд-во АН УзССР, 1953.

7. Напетваридзе Ш.Г. Сейсмостойкость гидротехнических сооружений. М.: Госстройиздат, 1959. 216 с.

8. Newmark N.H. Problems in wave propagation in soil and rock // Proc. of the Intern. Symp. on Wave Propagation and Dynamic Properties of Earth Materials. Univ. of New Mexico press. USA, New Mexico, 1968. P. 7-26.

9. Нормы проектирования атомных станций: НП 031-01. Москва, 2001.

10. Приложение 6. Основные положения расчета линейно-протяженных конструкций.

11. Рашидов T. Дифференциальное уравнение колебания подземного трубопровода при землетрясении // Докл. АН УзССР, 1962, № 9. С. 10-12.

12. Рашидов T. Исследование условий работы подземных трубопроводов при землетрясениях // Изв. АН УзССР. Сер. техн. наук, 1962, № 5. С. 44-52.

13. Рашидов T. Расчет подземного трубопровода на действие кратковременной и внезапно приложенной сейсмической нагрузки // Изв. АН УзССР. Сер. техн. наук, 1963, № 3. С. 49-58.

14. Рашидов T. Расчет подземных трубопроводов конечной длины на действие кратковременной сейсмической нагрузки // Докл. АН УзССР, 1963, № 4. C.13-16.

15. Рашидов T. О решении дифференциального уравнения колебания при сейсмических нагружениях подземного трубопровода и применение графика 
динамического коэффициента // Изв. АН УзССР. Сер. техн. наук, 1964, № 4. С. 21-29.

16. Уразбаев М.T., Рашидов Т. К вопросу сейсмостойкости сооружений, закрепленных на податливом повороту и сдвигу основании // Докл. АН УзССР, 1964, № 9. C.9-13.

17. Рашидов T. Динамическая теория сейсмостойкости сложных систем подземных сооружений. Ташкент: Изд-во "ФАН" УзССР, 1973. 180 с.

18. Рашидов T., Хожметов Г.X. Сейсмостойкость подземных трубопроводов. Ташкент: Изд-во "ФАН" УзССР, 1985. 154 с.

19. Исраилов М.Ш. Связанные задачи сейсмодинамики трубопровода // Вестн. Моск. ун-та. Сер. 1. Математика. Механика. 1996, № 5, с. 41-45.

20. Israilov M.Sh. Seismodynamics of an underground pipeline // Proc. of the 15-th World Conf. on Earthquake Engineering., Lisbon, Portugal, 2012. P. 2125.

21. Исраилов $M$. W. Сейсмодинамика подземного трубопровода // Проблемы механики (АН РУз). 2012. № 3. С. 18-24.

22. Георгиевский Д.В., Исраилов М.Ш. Сейсмодинамика протяженных подземных сооружений и грунтов: постановки задач и автомодельные решения //Изв. РАН. Механика твердого тела (МТТ). 2015, № 4. С. 138-151.

23. Гехман A. C. Научные основы сейсмостойкости магистральных трубопроводов. Дисс. ... Д. т. н. ВНИИГаз, 1993.

24. Исраилов М.Ш. Связанные сейсмические колебания трубопровода в бесконечной упругой среде // Изв. РАН. Механика твердого тела (МТТ). 2016, № 1. С. 57-66.

25. Исраилов М.Ш. Аналогия линейной цепочки атомов в сейсмодинамике подземного трубопровода // Вестн. Моск. ун-та. Сер. 1. Математика. Механика. 2015, № 1, с. 69-72.

26. Исраилов М.Ш. Некоторые новые результаты в динамике упругих сред и их приложения к сейсмодинамике подземных сооружений // XI Всероссийский съезд по фундаментальным проблемам теоретической и прикладной механики. Сб. докладов. Казань, 2015. С. 1635-1637.

27. Israilov M.Sh. Longitudinal seismic vibrations of a segmented pipeline considering as the periodically inhomogeneous rod // Proceedings of the 5-th Int. Conf. on Comp. Methods in Structural Dynamics and Earthquake Engineering (COMPDYN 2015). Eds.: M. Papadrakakis, V. Papadopoulos, V. Plevris. Crete, Greece, 2015. Vol. II, pp. 4663-4671.

28. Исраилов М.Ш. Новый подход в задачах о сейсмических колебаниях периодически неоднородных подземных трубопроводов // Вестн. Моск. ун-та. Сер. 1. Математика. Механика. 2016, № 1, с. 68-71.

29. Исраилов М.Ш. О гипотезе Ильюшина в сейсмодинамике подземных сооружений // Упругость и неупругость. М.: Изд-во Моск. ун-та, 2016. С. $323-$ 328.

30. Исраилов М.Ш. Сейсмодинамика протяженнных подземных сооружений: границы применимости инженерных подходов и неправомерность 
аналогии с наземными сооружениями // Сейсмостойкое строительство. Безопасность сооружений. 2017, № 1. С. 55-59.

31. Исраилов М.Ш., Акчаматова Л.Р. Стационарные сейсмические колебания трубопровода в вязкоупругом грунте // Вестн. Моск. ун-та. Сер. 1. Математика. Механика. 2017, № 3. С. 70-73.

32. Israilov M. Sh. and Takhirov Sh. M. Earthquake response of underground tubular structures: exact formulation of the problems and evolution of engineering approaches // Proc. of the 16-th European Conf. on Earthquake Engineering (16 ECEE). Tessaloniki, Greece, 2018. P. 1-11.

33. Исраилов М.Ш. Аналогия линейной цепочки и сейсмические колебания сегментных и вязкоупругих трубопроводов // Изв. РАН. Механика твердого тела (МТТ). 2018, № 3. С. 119-128. 